\title{
Effect of Organic Amendments and Gypsum on Physico Chemical Properties of Salt Affected Purna Valley Soils and Cotton Yield in Vidarbha Region
}

\author{
J. Ravinder*, N. M. Konde and V. K. Kharche \\ Department of Soil Science and Agricultural Chemistry, Post Graduate Institute, Dr. Panjabrao \\ Deshmukh Krishi Vidyapeeth, Akola, Maharashtra, 444104, India \\ *Corresponding author
}

\section{A B S T R A C T}

The field experiments on cotton were conducted on selected farmers' fields in Purna valley of Vidarbha region in Maharashtra during 2013-14.The treatments comprised of five

Keywords

Gypsum, green

manure,

amelioration,

amendments

Article Info

Accepted:

10 August 2017

Available Online:

10 September 2017 different green manures, two crop residues, gypsum and control. There were nine treatments replicated on three farmers' fields. The design of experiment was randomized block design, replicated three times, where one farmer was treated as one replication. The use of crop residues and green manuring was found beneficial as that of gypsum in physical properties of the soils in addition to gradual chemical amelioration. Although considerable improvement in chemical properties has been observed under gypsum indicating reduction in $\mathrm{pH}$ from the average initial of 8.31 to 8.19 and ESP from average initial of 11.15 to 7.12 , but simultaneously the significant reduction has also been observed under organic amendments like dhaincha and sunhemp. The organic amendments were also found useful and superior to gypsum in improving the organic carbon available NPK and biological properties of soil. The organic amendments showed their potential not only for slow reclamation but also for improvement in characteristics of sodic soils. The organic amendments like dhaincha and sunhemp were found equally beneficial for obtaining crop yields as that of gypsum besides gradual soil reclamation.

\section{Introduction}

The Purna valley is the unique tract of Vertisols in Vidarbha region (M.S.) of India having combination of three fold problems, the native salinity, poor drainability and poor quality of ground water. These soils of are developed on basaltic alluvium under arid and semi-arid conditions have clay mineralogy. The Purna valley of Vidarbha region is an east-west elongated basin with slight covering to the south occupying the part of Amravati, Akola and Buldhana districts of Vidarbha and extends from $20^{\circ} 45^{\prime}$ to $21^{\circ} 15^{\prime} \mathrm{N}$ latitude and $75^{\circ} 25^{\prime}$ to $77^{\circ} 45^{\prime}$ E longitude with east-west length of 100-150 km having width of about 10 to $60 \mathrm{~km}$ covering an area of about 4.69 lakh hectares distributed in Amravati (1738 sq. km), Akola (1939 sq. km) and Buldhana (1015 sq. km). The salts have varying degree of deterioration i.e. salinity or sodicity and salinity-sodicity (Anonymous, 2010). These soils are having high swell-shrink potential, slow permeability with very low hydraulic conductivity and poor drainage conditions. Taxonomically these salt affected soils are classified as Sodic Haplusterts and Sodic Calciusterts (Padole et al., 1998). Cotton 
"white gold" (i spp.) the king of fibres is premier cash crop of central and western part of country with enormous potential in employment generation and economic trade activity. The average production of lint in India during 2013-14, was 35.20 million bales and in Maharashtra it was 8.50 million bales (Anonymous, 2013).

\section{Materials and Methods}

The experiment was carried out to study the effect of crop residues, green manuring and gypsum on soil properties and yield of cotton in salt affected soils of Purna valley in Vidarbhaon farmers' fields in Kutasa village during $2013-14$. Which is $32 \mathrm{~km}$ from Akola, $19 \mathrm{~km}$ from Akot and $20 \mathrm{~km}$ from Daryapur. The Kutasa village lies about $10 \mathrm{~km}$ away from the Purna River. The materials used and methods adopted are discussed in this chapter under the following heads. The exploratory borehole data indicated the basement (Deccan basalt) to be an uneven platform sloping northerly or west northwesterly towards depressed region of Akot and Bawanbir. The upper cover of the alluvial deposit comprises three lithostratigraphic formations (Tiwari and Mukhopadhyay, 1989), which is decreasing in order of the antiquity are the virual formation, the kural formation and the Purna formation. The virual formation forms morpho stratigraphic units referable to the older and the younger (present) alluvium deposits, while the Purna formation is observed only inthe bank formation observed only in the bank sections. The virual formation isoverlain by either the kural formation or the Purna formation with an erosional unconformity. Cotton was grown in kharif and green manuring crops were sown in between two rows of cotton which are buried subsequently in soil. The cotton stalk residues were decomposed using decomposing culture and applied to the soil before sowing. The crop residues available on farm viz., pigeon pea, soybean, sorghum stubbles and chickpea residues were utilized as biomulch. Gypsum application was made to the respective treatment plots uniformly by mixing in the top ten centimeter layer. The crop residues from the crops were incorporated into soil of respective treatments after harvest of the crops so as to ascertain their residual effect. The soil of the experimental field comprised of clayey montmorillonitic, deep with soil order Vertisols.

\section{Methods Adopted}

Collection of plot wise soil samples of the experimental sites before sowing in kharif and Collection of plot wise soil samples $(0-20$ cm depth) after harvest of cotton was carried out. Analysis of soil for physical and chemical properties has been carried out. Soil bulk density was determined by clod coating technique as described by Blake and Hartge (1986). Hydraulic conductivity was determined by constant head method as described by Klute and Dirksen (1986).Hydrogen ion activity expressed as $\mathrm{pH}$ is determined by potentiometry using 1:2 soil water suspension (Jackson,1973). The clear water supernatant obtained from the suspension used for $\mathrm{pH}$ was utilized for the EC measurement using conductivity bridge (Jackson, 1973).Available N, P, K alkaline permanganate method as described by Subbiah and Asija (1956). Olsen's method as described by Watanabe and Olsen using 0.5 $\mathrm{M}$ sodium bicarbonate $\mathrm{pH}$ (8.5) as an extractant. Darco-G-60 soluble phosphorus was used to absorb the dispersed organic matter and make the filtrate colourless for further colorimetric analysis. (Watanabe and Olsen, 1965). Flamephotometer using neutral $\mathrm{N}$ ammoniumacetate (pH 7.0) as an extractants described by Hanway and Heidel (1952), respectively. The saturated paste was prepared and the extract was obtained. The 
method described by Richards (1954) was followed for the saturation extract preparation. The saturation extracts of the soil samples were analysed for $\mathrm{pHs}$, electrical conductivity (ECe) and cations and anions as per the methods outlined by Richards (1954).Soil was saturated with $1 \mathrm{~N} \mathrm{NaOAC}$ (sodium acetate $\mathrm{pH}$ 8.2), after removal of excess, sodium acetate by washing with alcohol, the adsorbed sodium was extracted by washing with $1 \mathrm{~N} \mathrm{NH4OAC} \mathrm{(ammonium}$ acetate $\mathrm{pH}$ 7) and the leachate was made upto known volume. $\mathrm{Na}+$ present in the leachate was determined with flame emission spectrophotometer (Jackson, 1973)

\section{Statistical analysis}

The data on different parameters were tabulated and analysed statistically by the methods described by Panse and Sukhatme (1971).Exchangeable sodium percentage (ESP) were derived by using following formulae :

$\mathrm{ESP}=$ Exchangeable sodium/CEC $\mathrm{x} 100$, $\mathrm{CEC}$ and ESP were expressed in $\mathrm{cmol}(\mathrm{p}+) / \mathrm{kg}$

\section{Results and Discussions}

The results obtained from this investigation are presented and discussed accordingly. The lowest bulk density hasbeen recorded under dhianchain situ green manuring $(1.57 \mathrm{Mg} \mathrm{m}-3)$ while it was found highest in control $(1.65 \mathrm{Mg}$ $\mathrm{m}-3$ ) where no residue, no green manure was applied The slight reduction in bulk density was recorded under all the treatments viz., sunhemp in situ green manuring (T2), leucaenaloppings green leaf manuring (T4), cowpea in situ green manuring (T5), green gram in situ green manuring (T6), composted cotton stalk residue (T7), biomulch (T8)and gypsum@2.5 t/ha (T9). However, the bulk density was least influenced under the control (T1). The only slight variation caused may be due to less period. However, theresults indicate the potential benefit of residue and green manuring. Bharambe et al., (2001) observed significantr eduction in bulk density of sodic Vertisols of Parbhani byincorporation of dhianchainsitu green manuring or sugarcane trash @ $5 \mathrm{t} / \mathrm{ha}$. Similar results were also reported by Kaur et al., (2008), Choudhary et al., (2011). The enhancement in hydraulic conductivity is attributed tothe reclamation of soil. Replacement of sodium by calcium due to addition of gypsum gradually helps in flocculation process resulting in better aggregation, which have caused decrease in bulk density and improvement in hydraulic conductivity (Patel and Suthar, 1993) The significant reduction was observed in soil $\mathrm{pH}$ from 8.31(initial) to 8.18 (gypsum) followed by sunhemp (8.23), dhaincha (8.23) in situ green manuring and composted cotton stalk residue (8.28).

Application of organic amendments could be attributed to acidifying effect of organic amendments. These observations are in conformity with Singh et al., (2011), Choudhary et al., (2011). The faster reclamation observed under the gypsum application as compared to the reduction at green manures and residues is due to faster reclamation of sodic soils; however the results reveal the potential utility of green manure and crop residues in reducing $\mathrm{pH}$ of sodic soils. This is beneficial for improving soil fertility in sodic soils. Electrical conductivity of soil was found to be low at almost all the treatments under study and found well below the critical limit of soil electrical conductivity to cause salinity Similar results were also reported by Choudhary et al., (2011) and who showed that application of organic and inorganic amendments increase electrical conductivity initially but decrease the same subsequently due to creation of favourable soil physical condition. The significant results of CEC are obvious owing to the fact that 
CEC is the intrinsic static primary property of soils which largely governed by mineralogical make up and very slightly and rarely modified. In general high CEC of the soils is attributed to the high clay content of smectitic nature. Among the treatments of organic amendments application of sunhempinsitu green manuring $(54.85 \mathrm{cmol}(\mathrm{p}+) / \mathrm{kg})$ recorded the highest value. Maurya et al., (2009) reported that application of gypsum along with organic amendments or alone application of organic amendments increased CEC. The increase in CEC with added organic amendments may be due to production of organic metabolites rich in carboxylic and phenolic compounds in soil.

Table.1 Treatment details

\begin{tabular}{|l|l|l|}
\hline Treatment No. & Cotton & Greengram-Chickpea \\
\hline T1 & No residue No green manure (Control) & Residual effect \\
\hline T2 & Sunhemp in situ green manuring & Residual effect \\
\hline T3 & Dhaincha in situ green manuring & Residual effect \\
\hline T4 & Leucaenaloppings green leaf manuring & Residual effect \\
\hline T5 & Cow pea in situ green manuring & Residual effect \\
\hline T6 & Green gram in situ green manuring & Residual effect \\
\hline T7 & Cotton stalk residue composted with PDKV decomposer & Residual effect \\
\hline T8 & Mulching with farm waste with PDKV decomposer & Residual effect \\
\hline T9 & Gypsum @ 2.5 t/ha & Residual effect \\
\hline
\end{tabular}

Table.2 Initial physical and chemical properties of soil (2011-12)

\begin{tabular}{|c|c|c|c|c|}
\hline Sr.No. & Particulars & Site-I & Site-II & Site-III \\
\hline $\mathbf{A}$ & \multicolumn{4}{|l|}{ Physical properties } \\
\hline 1 & Hydraulic conductivity (cm h-1) & 0.58 & 0.53 & 0.49 \\
\hline 2 & $\mathrm{BD}(\mathrm{Mg} \mathrm{m}-3)$ & 1.63 & 1.62 & 1.63 \\
\hline $\mathrm{B}$ & \multicolumn{4}{|l|}{ Chemical properties } \\
\hline 1 & $\mathrm{pH}(1: 2)$ & 8.27 & 8.32 & 8.34 \\
\hline 2 & $\mathrm{EC}(1: 2 \mathrm{dS} \mathrm{m}-1)$ & 0.20 & 0.22 & 0.25 \\
\hline 3 & Organic carbon (g kg-1) & 5.43 & 5.71 & 5.23 \\
\hline 4 & $\mathrm{CaCO} 3(\%)$ & 10.29 & 10.60 & 9.67 \\
\hline 5 & \multicolumn{4}{|l|}{ Exchangeable cations $(\mathrm{cmol}(\mathrm{p}+) \mathrm{kg}-1)$} \\
\hline & $\mathrm{Ca}$ & 27.60 & 28.0 & 27.40 \\
\hline & $\mathrm{Mg}$ & 16.0 & 16.0 & 16.4 \\
\hline & $\mathrm{Na}$ & 6.0 & 5.91 & 5.82 \\
\hline & $\mathrm{K}$ & 0.95 & 0.92 & 0.98 \\
\hline 6 & $\mathrm{CEC}(\mathrm{cmol}(\mathrm{p}+) \mathrm{kg}-1)$ & 53.47 & 53.04 & 52.17 \\
\hline 7 & ESP & 11.22 & 11.14 & 10.39 \\
\hline 8 & Base saturation $(\%)$ & 94.53 & 95.83 & 96.99 \\
\hline $\mathbf{C}$ & \multicolumn{4}{|l|}{ Saturation paste extract analysis } \\
\hline 9 & $\mathrm{pHs}$ & 8.24 & 8.26 & 8.29 \\
\hline 10 & $\mathrm{ECe}(\mathrm{dS}$ m-1) & 1.05 & 1.12 & 1.01 \\
\hline \multirow[t]{5}{*}{11} & Soluble cations & & & \\
\hline & $\mathrm{Ca} 2+($ me L-1) & 2.8 & 3.0 & 2.6 \\
\hline & $\mathrm{Mg} 2+($ me L-1) & 3.8 & 4.0 & 4.8 \\
\hline & $\mathrm{Na}+($ me L-1) & 4.5 & 4.7 & 5.1 \\
\hline & $\mathrm{K}+($ me L-1) & 0.58 & 0.53 & 0.56 \\
\hline \multirow[t]{5}{*}{12} & Soluble anions & & & \\
\hline & $\mathrm{CO}^{-2}$ (me L-1 & ---- & ----- & ----- \\
\hline & HCO3-(me L-1) & 7.5 & 5.0 & 8.0 \\
\hline & SO4 2-(me L-1) & 4.98 & 4.51 & 4.36 \\
\hline & $\mathrm{Cl}-(\mathrm{me} \mathrm{L}-1)$ & 2.0 & 1.2 & 0.8 \\
\hline
\end{tabular}


Table.3 Physical properties as influenced by different treatments

\begin{tabular}{|l|l|l|l|l|}
\hline \multirow{2}{*}{ Tr. No. } & Treatment & BD (Mg m-3) & HC $(\mathbf{c m} / \mathbf{h})$ \\
\cline { 2 - 4 } & Cotton & $\begin{array}{l}\text { Green } \\
\text { Chickpea }\end{array}$ & gram- \\
\hline T1 & $\begin{array}{l}\text { Control (No residue No } \\
\text { green manure) }\end{array}$ & Residual effect & 1.65 & 0.54 \\
\hline T2 & $\begin{array}{l}\text { Sunhempin situ green } \\
\text { manuring }\end{array}$ & Residual effect & 1.59 & 0.58 \\
\hline T3 & $\begin{array}{l}\text { Dhaincha in situ green } \\
\text { manuring }\end{array}$ & Residual effect & 1.57 & 0.60 \\
\hline T4 & $\begin{array}{l}\text { Leucaenaloppings } \\
\text { green leaf manuring }\end{array}$ & Residual effect & 1.61 & 0.57 \\
\hline T5 & $\begin{array}{l}\text { Cow pea in situ green } \\
\text { manuring }\end{array}$ & Residual effect & 1.61 & 0.58 \\
\hline T6 & $\begin{array}{l}\text { Green gram in situ green } \\
\text { manuring }\end{array}$ & Residual effect & 1.60 & 0.58 \\
\hline T7 & $\begin{array}{l}\text { Composted cotton stalk } \\
\text { residue }\end{array}$ & Residual effect & 1.58 & 0.57 \\
\hline T8 & $\begin{array}{l}\text { Biomulch (Mulching with } \\
\text { farm waste) }\end{array}$ & Residual effect & 1.60 & 0.58 \\
\hline T9 & Gypsum @ 2.5 t/ha & & 1.62 & 0.61 \\
\hline SE (m) \pm & & & 0.0136 & 0.01 \\
\hline CD at 5\% & & & 0.041 & 0.03 \\
\hline $\begin{array}{l}\text { Initial } \\
(2011-12)\end{array}$ & & & 1.62 & 0.53 \\
\hline
\end{tabular}

Table.4 Chemical properties as influenced by different treatments

\begin{tabular}{|c|c|c|c|c|}
\hline \multirow[t]{2}{*}{ Tr. No. } & \multicolumn{2}{|l|}{ Treatment } & \multirow[t]{2}{*}{$\mathrm{pH}(1: 2)$} & \multirow{2}{*}{$\begin{array}{l}\text { EC (1:2) } \\
(\mathrm{dS} / \mathrm{m}-1)\end{array}$} \\
\hline & Cotton & Green gram-Chickpea & & \\
\hline T1 & $\begin{array}{l}\text { Control (No residue No } \\
\text { green manure) }\end{array}$ & Residual effect & 8.23 & 0.26 \\
\hline $\mathrm{T} 2$ & $\begin{array}{l}\text { Sunhempin situ green } \\
\text { manuring }\end{array}$ & Residual effect & 8.23 & 0.26 \\
\hline T3 & $\begin{array}{l}\text { Dhaincha in situ green } \\
\text { manuring }\end{array}$ & Residual effect & 8.29 & 0.26 \\
\hline $\mathrm{T} 4$ & $\begin{array}{l}\text { Leucaenaloppings } \\
\text { green leaf manuring }\end{array}$ & Residual effect & 8.23 & 0.26 \\
\hline T5 & $\begin{array}{l}\text { Cow pea in situ green } \\
\text { manuring }\end{array}$ & Residual effect & 8.28 & 0.27 \\
\hline T6 & $\begin{array}{l}\text { Green gram in situ green } \\
\text { manuring }\end{array}$ & Residual effect & 8.28 & 0.28 \\
\hline $\mathrm{T} 7$ & $\begin{array}{l}\text { Composted cotton stalk } \\
\text { residue }\end{array}$ & Residual effect & 8.18 & 0.26 \\
\hline $\mathrm{T} 8$ & $\begin{array}{l}\text { Biomulch (Mulching with } \\
\text { farm waste) }\end{array}$ & Residual effect & 8.32 & 0.34 \\
\hline T9 & Gypsum @ 2.5 t/ha & & 8.32 & 0.27 \\
\hline $\mathrm{SE}(\mathrm{m}) \pm$ & & & 0.009 & 0.011 \\
\hline $\mathrm{CD}$ at $5 \%$ & & & 0.03 & 0.03 \\
\hline $\begin{array}{l}\text { Initial (2011- } \\
\text { 12) }\end{array}$ & & & 8.31 & 0.22 \\
\hline
\end{tabular}


The application of organic and gypsum was found effective in removing soluble anions in soluble phase).Among the organic amendments dhaincha in-situ green manuring and sunhemp in-situ green manuring was found most effective in reducing bicarbonate concentration. Patel and Singh (1991) studied comparative effect of gypsum, pyrite and pressmud on composition of leachate and soil properties. The results of their findings showed that gypsum and pressmud application were most effective in removing $\mathrm{CO} 2-3$ and HCO-3 respectively. As regards chlorides and sulphates they were also reduced significantly due to organics (T2-T8) and gypsum (T9) application.

In respect of seed cotton yield as influenced by various green manuring and crop residues was found significant. The highest seed cotton yield (13.52 q/ha) was obtained with the application of gypsum @ $2.5 \mathrm{t} /$ ha followed by application of green gram, dhaincha, sunhemp in situ green manuring which were on par with each other. In respect of cotton stalk yield significantly highest yield was recorded under the application of Gypsum @ 2.5 tones/ha, followed by dhaincha, sunhemp green gram and cow pea in situ green manuring which were on par with each other. The lowest cotton stalk yield was observed under control treatment.

The use of crop residues and green manures were also beneficial in improving physical and chemical properties of soil as well as indicating the potential for soil reclamation. Similarly application of gypsum recorded significant improvement in physical and chemical properties of soils resulting into noticeable enhancement in crop yield. In the same manner organic amendments like dhaincha and sunhemp were also found equally beneficial for obtaining crop yields as that of gypsum besides gradual soil reclamation.

\section{Acknowledgements}

We are thankful to farmers of Kutasa village for their keen co-operation and support also for their hospitality during entire project in their fields.

\section{References}

Anonymous, 2010. Soil resource management for sustainable soil health and food security state level seminar held at a Dr. P.D.K.V, Akola, 2-3 Jan. pp 138-144.

Anonymous, 2013. "Statistics at a Glance" Department of Agriculture and Cooperation, Ministry of Agriculture, Govt. of India, http://agricoop.nic.in/Agristatstics.htm.

Bharambe, P.R., D.K. Shelke, G.S. Jadhav, V.G. Vaishnava and S.R. Oza. 2001. Management of salt affected Vertisols with sub-suface drainage and crop residue incorporation under soybeanwheat cropping system. J. Indian Soc. Soil Sci. 49 (1): 24-29.

Blake, G.R., and K.H. Hartge, 1986. Bulk density. In: Methods of Soil Analysis, Part-I, Klute, A. (Ed.). American Society of Agronomy Inc. and Soil Science Society of America Inc. Madison, Wisconsin, USA, pp. 371373.

Choudhary, O.P., B.S. Ghuman, Bijay Singh, N. Thuy and R.J. Buresh. 2011. Effect of long term use of sodic irrigation, amendments and crop residues on soil properties and crop yields in rice-wheat cropping system in a calcareous soil. Field Crop Research 121: 363-372.

Hanway, J.J., and H. Heidel, 1952. Soil Analysis Methods, as used in Iowa State.College Soil Testing Laboratory, Iowa, Agriculture. 57:1-31.

Jackson, M.L., 1973. Soil Chemical Analysis (Edn. 2) Prentice Hall of India Pvt. Ltd., New Delhi. pp. 69-182. 
Kaur, J., O.P. Choudhary and B. Singh. 2008. Microbial biomass carbon ans some soil properties as influenced by long term sodic water irrigation, gypsum and organic amendments. Aust. J. of Soil Res. 46: 141-151.

Klute, A., and C. Dirksen, 1986. Hydraulic conductivity and diffusivity, laboratory methods.In Methods of Soil Analysis Part-I. Ed. Klute, A. Agron. Monogrpah 9, Madison, Wisconsin. pp. 716-719.

Maurya, B.R., H. Ram and S.S. Prasad. 2009. Impact of soil amendments on properties of the salt affected rice soil. J.Indian Soc. Soil Sci. 57 (3): 385-388.

Padole, V.R., R.K. Chakolkar and P.W. Deshmukh, 1998. Characterization of salt affected Vertisols of Vidarbha region of Maharashtra. PKV Res. J. 22:
26-34.

Panse, V.G., and P.V. Sukhatme. 1971. Statistical Methods for Agricultural Workers. ICAR, New Delhi, pp- 110113.

Patel, M.S., and D.M. Suthar. 1993. Effect of gypsum on properties of sodic soils, infiltration rate and crop yield. J.Indian Soc. Soil Sci. 41 (4): 802-803.

Subbiah, B.V., and G.L. Asija. 1956. A rapid procedure for the estimation of available nitrogen in soils. Curr. Sci. 25: 259-260.

Watanabe, F.S., and S.R. Olsen, 1965. Test of ascorbic acid method for determining phosphorus in water and sodium bicarbonate extracts of soils. Proc. Soil Sci. Soc. Am., 29: 677-678.

\section{How to cite this article:}

Ravinder J., N. M. Konde and Kharche V. K. 2017. Effect of Organic Amendments and Gypsum on Physico Chemical Properties of Salt Affected Purna Valley Soils and Cotton Yield in Vidarbha Region. Int.J.Curr.Microbiol.App.Sci. 6(9): 3741-3747. doi: https://doi.org/10.20546/ijcmas.2017.610.462 